\title{
Technology of processing CT data of the Knee Joint
}

Sedlák Josef, M.Sc. Ph.D., Charvát Ondřej, M.Sc., Madaj Martin, M.Sc.,

Institute of Manufacturing Technology, Faculty of Mechanical Engineering, Brno University of Technology

\begin{abstract}
Aloarthroplastic is the basic surgery method in orthopaedics, which handles the insult to the normal human joint function [1]. Achieving of advance in development of knee replacements is possible only on the basis of complex and deep knowledge of those problems and on experimental judgment of physical properties of used materials including successful implantation before introduction into the practice. In orthopaedics, technology of 3D models creation and theirs application is at the beginning and there is an effort to decide what effective manner has to be used for total benefit from the viewpoint of patient medication. This long-term task can be verified only in practice.
\end{abstract}

Keywords: Knee Joint, Reverse Engineering, CAD software, Rapid Prototyping, CT data.

\section{References}

[1] NEDOMA, J., et al. Biomedicíncká informatika II: Biomechanika lidského skeletu a umělých náhrad jeho částí. [online]. 2006 [cit. 5. dubna 2009]. Dostupné na World Wide Web: $<$ http://ucebnice.euromise.cz/index.php?conn=0\&section=biomech $>$. ISBN 80-246-1227-5.

[2] HAJNÝ, P. Totální náhrada kolenního kloubu. Doporučené postupy. Projekt MZ ČR zpracovaný ČLS JEP za podpory grantu IGA MZ ČR 5390-3. 2002.

[3] Centrum Prof. ČECHA s.r.o. Česká republika. Anatomie kolenního kloubu. [online]. Leden 2009 [cit. 10. ledna 2009]. Dostupné na World Wide Web: <http://www.ortopedie.cz/web/webok.html>.

[4] BRUNS, J., VOLKMER, M., LUESSENHOP, S. Pressure distribution at the knee joint. Archives of Orthopaedic and Trauma Surgery. Volume 113, Number 1/ December, 1993, p. 224.

[5] PAPACHRISTOU, G. Photoelastic study of the internal and contact stresses on the knee joint before and after osteotomy Journal. Archives of Orthopaedic and Trauma Surgery. Volume 124, Number 5/June, 2004, p. 533.

[6] WATANABE, H., AHMED, A. R., SHINOZAKI, T., YANAGAWA, T., TERAUCHI, M., TAKAGISHI, K. Reconstruction with autologous pasteurized whole knee joint II. Application for osteosarcoma of the proximal tibia. In Journal of Orthopaedic Science. Volume 8, Number 2/March, 2003, p. 676.

[7] VALENTÍNÍN, J. R., LEYES, M., SCHWEITZER, D. Spontaneous osteonecrosis of the knee. Treatment and evolution. Journal Knee Surgery, Sports Traumatology, Arthroscopy. Volume 6, Number 1/January, 1998, p. 112.

[8] SEDLÁK, J., PÍŠKA, M. Výroba implantátů. MM prưmyslové spektrum. 2008. roč. 2008, č. 3, s. 74-75. ISSN $1212-$ 2572.

[9] ZOUHAR, J., PÍŠA, Z., SEDLÁK, J., SEDLÁČEK, J. Produktivní obrábění s využitím metod reverzního inženýrství. In Sborník odborné konference „Frézování IV“. Brno: VUT-FSI, Ústav strojírenské technologie ve spolupráci s PRAMET TOOLS, s.r.o. Sumperk a ZPS - Frézovací nástroje, a.s., Zlín, 31.1.2007. s. 189-196. ISBN 80-2143239-X.

[10] BEZNOSKA s.r.o. Česká republika. Vertikální frézovací a vrtací centrum HAAS. [online]. Srpen 2003 [cit. 26. února 2009]. Dostupné na World Wide Web: <http://www.beznoska.cz/indexm.php?a=text\&id=41\&lan=cz>.

[11] PROCHÁZKOVÁ, J. Modelováni matematických ploch v CAD systémech: Disertační práce. Brno: Vysoké učení technické v Brně, Fakulta strojního inženýrství, Ústav matematiky, červen 2007. 163 s. Vedoucí disertační práce doc. PaedDr. Dalibor Martišek, Ph.D.

[12] PROCHÁZKOVÁ, J., PROCHÁZKA, D. The application of nurbs surfaces in engineering practice. Sborník konference „, Moderní matematické metody v inženýrstvi". Brno: Vysoké učení technické v Brně, Fakulta strojního inženýrství, Ústav matematiky, 2006.

[13] SEDLÁK, J., PROCHÁZKOVÁ, J. Direct B-Spline Interpolation of CNC Tool Trace From Cloadpoints. Strojírenská technologie. 2007. roč. 12, č. 2, 1-4 s. ISSN 1211-4162.

[14] PROCHÁZKOVÁ, J., SEDLÁK, J., PROCHÁZKA, D. Direct B-Spline Interpolation of CNC Path From Cloud of Points. In Proceedings of symposium on computer geometry SCG 2007. Bratislava: STU Bratislava, 2007. s.104109. ISBN: 978-80-227-2734-1.

[15] SEDLÁK, J., PROCHÁZKOVÁ, J. Direct B-Spline Interpolation of CNC Tool Trace From Cloadpoints. Manufacturing Technology. 2007. roč. 7, č. 1, s. 66-71. ISSN 1213-2489. 
Reviews:

Prof. Bohumil Bumbálek, MSc., Sc.D. Prof. Karel Jandečka, MSc., Ph.D. 